\title{
Challenges associated with Adoption of Agency Banking and Bank Performance: A Case of Selected Commercial Banks in Kenya
}

\author{
Edwin Henry Mutura Mungai, MBA ${ }^{1}$ \\ Job Omagwa, PhD ${ }^{2}$
}

\begin{abstract}
The study sought to determine the effect of challenges associated with adoption of agency banking on bank performance of four selected commercial banks in Kenya. Empirical evidence indicates that the effects of challenges associated with adoption of agency banking on bank performance in Kenya are positive and that there is relationship between accessibility of banking services, low cost of service and customer transactions as a result of agency banking. The study employed purposive sampling to obtain a sample of 44 respondents from four banks. Data was collected using questionnaires. The findings of the study indicate that administrative challenges do not significantly affect bank performance whereas reliability and operational challenges were found to have a significant effect on bank performance. The study concluded that the banks needs to do more in containing some of the challenges studies since they impacted on agency banking as a product generally. Based on the findings, the study made recommendations to commercial banks management, academicians and policymakers. The study recommended that policy makers heighten awareness to the public through regular open day forums, media and exhibitions on the need and use of agency banking, and develop strategies that will capture new customers. Banks should also be allocating more resources to most especially minimize liquidity problems. The study finally suggested further research on the effects of adoption of agency banking on other upcoming agencies for other commercial banks and microfinance institutions.
\end{abstract}

Keywords: agency banking, bank performance, bank agent and commercial banks.

\section{Introduction And Background}

Commercial banks are essential for each other economy; consistent economic growth may not be achieved unless savings are efficiently channeled into investment. The lack of a fully-fledged banking system has been identified as a major weakness of the centrally planned economies (Nefa, 2013). Banks have been delivering electronic services to consumers and businesses for years. Banks are early users of technology and core drivers of technological advancement: Electronic fund transfer (EFT), automated teller machine (ATM), cash deposits (CAD), cash withdrawals (CAW) and forex (Oyanda, 2015). Despite these agency banking services, it remains unclear if challenges associated with the same have a significant effect on bank performance.

Financial innovations are used by banks as strategic variables to outdo competitors and are essential means for banks to improve its performance and maintain effectiveness on the market (Berger, Demirgüç-Kunt, Levine, \& Haubrich, 2004). This stimulates interest in studying the relationship between financial innovations and bank performance. In a competitive environment, a successful innovation creating a unique competitive position can give a bank a competitive advantage and lead to a superior financial performance (Muiruri \& Ngari, 2014). This can only be maintained by ceaseless innovation and improvement of the product and process (Allen $\&$ Gale, 2004). Despite undeniable need for financial innovation in explaining banking performance, the impact of innovation on financial performance is still misunderstood for two main reasons: lack of understanding about drivers of innovation and innovation's impact on financial performance.

Agency banking refers to contracting of a retail outlet whether corporate or a small market enterprise by a financial institution or mobile network operator to process bank client's transactions (Calleo, 2014). Sahut (2011) defines agency banking as systems that enable bank customers to access accounts and general information on bank products and services through a personal computer or an intelligent device or any other banking activity held on internet. Agency banking is different from a bank cashier or teller in that the owner conducts the transactions such as cash deposit, cash withdrawal, electronic fund transfers, and payment of bills,

\footnotetext{
${ }^{1}$ Family Bank Limited, Kenya: Email: Mungaie@ familybank.co.ke

${ }^{2}$ Kenyatta University, School of Business: Email: omagwa.job@ku.ac.ke
} 
account balance enquiry and loan referrals. Agents operate in supermarkets, pharmacies, retails shops and convenience stores (Sahut, 2011).

Bank performance is the degree of accomplishment for banking financial objectives, the banks accomplishment on customer satisfaction and retention, banks deposit, targets and new account opening, banks profit after tax and banks accessibility, flexibility and technological innovations and its applicability into the market as a competitive advantage defines a bank's competitive edge (Aburime, 2008). This is a banks fulfillment of an obligation, in a manner that releases the performer from all liabilities under the contract. Financial perspectives, customer perspectives, internal processes, learning and growth divide the bank into tire one bank or tire two banks (Karani, 2013). The bank performance measures adopted for purposes of this study were: Transaction time, profitability, loan book and liquidity.

\subsection{Commercial Banking in Kenya}

As at $31^{\text {st }}$ December, 2015, the banking sector comprised of the CBK, as the regulatory authority, 43 banking institutions, 35 commercial banks and 1 mortgage finance company, 2 representative offices of foreign banks, 5 deposit taking microfinance institutions (DTM) and 126 forex bureaus. Thirty of the banking institutions are locally owned while thirteen are foreign owned (CBK, 2015). Commercial banks are important to the economy and play strategic roles. Direct investments such as loans both long term and short term, provide maturity intermediation by creation of more option in the length of debt, risk reduction by diversification this being transferring more risky assets into less risky one, providing payment mechanisms other than CAW and CAD commercial banks clear cheques, EFT, debit card and credit card modes of payment, collecting and processing information in order to gauge risks of various investments and value them accordingly (Kiragu et al., 2006). Commercial banks have numerous outlets to serve customers globally, nationally and locally. Reducing turnaround time in transactions as well as safe keeping of money earned. To improve on service, commercial banks have opened up agencies that are agency banking, that are local businessmen and women to collect funds for them. The official start of applied technological advancement in the banking sector was in 1995, witnessed by the first electronic bank (Saropa, 2013).

\section{Statement Of The Problem}

The commercial banking sector is important to the Kenyan economy due to its contribution to mobilization of resources and the fact that several other sectors of the economy depend much on the banking sector for sourcing of funds and as an investment option. Financial innovations are therefore,very essential in the commercial banking sector due to profit and wealth maximization. Kenyan customers are yet to appreciate agency banking services as compared to the use of mobile banking (Mosoti \& Mwaura, 2014). However, adoption of agency banking comes with challenges that are bound to influence bank performance. Despite the significance of the sector to the kenyan economy, it remains unclear if adoption of agency banking in commercial banking sector has a significant effect on bank performance.

Irura and Munjiru (2013) studied challenges of implementing agency banking in Kakamega County, Kenya. The study found out that implementation could be explained by fraud, literacy level, technological issues and liquidity problems. The findings did not clearly establish whether liquidity, fraud, technological issues and literacy were the only hindrances to the implementation of agency banking in Kenya. Agalla (2014) sought to establish challenges facing implementation of agency banking at Kenya Commercial Bank, with an objective of establishing whether risks associated with agency banking, policies and procedures governing agency banking, technological operations and awareness were hindrances to the implementation of agency banking. The Agalla (2014) study found out that resource allocation, ineffective technology and lack of staff training on relevant technology were the key challenges. Despite these challenges, it is not quite clear on the effect of the same on bank performance. Hence, in view of the study problem, the study sought to achieve the following specific objectives: to determine the effect of agency banking administrative challenges on bank performance; to determine the effect of reliability of agency banking on bank performance; and to ascertain the effect of agency banking operational challenges on bank performance.

\section{Review Of Literature}

The section reviews general theoretical literature and empirical literature relevant to the study.

\subsection{Theoretical Literature}

The study was based on three theories: agency theory, intermediation theory and mobile banking business model. Agency theory explains the relationship between principal and agent in business and addresses the problems that arise when the desires or goals of the principal and agent are in conflict; and the problem that arise when the principle and agent have different attitude3s towards risk (Jensen \& Meckling, 1976). Intermediation theory is premised on enticing investors to buy securities backed by investments whose risks the investor cannot fully evaluate. The theory of intermediation have been built on the models of resource allocation 
based on perfect and complete markets by suggesting that it is frictions such as transaction costs and asymmetric information that are important in understanding intermediation (Gurley \& Shaw, 1960). Mobile Banking Business Model indicates that agency banks networks increase banks outreach and provide attractive way for banks to reach population that was bank less. Use of ICT reduces the cost and increases the reach of banking, making correspondents an attractive vehicle for the underserved low income population (Kumar, 2005).

Agency banking has a broad range of financial services outside convectional bank branches and involves agents. Agency banking in Latin America and Brazil are the most developed (Hussain, 2014). Developing countries are accepting agency banking as a means of banking the unbanked population. As per 2009 national financial access survey, $33 \%$ is not utilizing banking services. Inaccessibility is the main driver, travelling long to get the banking services. Agencies have reduced set up and delivery costs, CAD and CAW on a larger scale to customers who feel safer banking at their local merchants (Mas \& Radcliffe, 2011). Mandrile (2010) argued that traditional branch based retails banking remains the most widespread method for conducting banking transactions in Kenya. However, agency banking technology is rapidly changing the way personal financial services are being designed and delivered. For several years, commercial banks in Kenya have tried to introduce agency banking based electronic banking system to improve their operations and reduce costs. (Lee et al., 2007) indicates that technology will therefore create greater opportunities to service providers to offer great flexibility to customers. To this end commercial banks are fast adopting branchless banking ATM, internet and mobile banking.

\subsection{Empirical Review}

The study reviewed various studies in view of the study variables and study conceptualization. Karimi (2011) established that there is difficulty in enforcing appropriate oversight by the agent and customer interaction was inconsistent with overall banking regulatory framework. The findings revealed the need for regular training of agents on changes in operational processes and policies in order to eradicate occurrence of error and mistakes that obstruct penetration of agency banking in Kenya thus enhance banks' financial performance. Kithuka (2012) study found that distance was a non-factor to customers and their transactions. Banking agents and the bank itself coordination influences the growth of agency banking in Kenya. The study recommends further research on customer satisfaction and how it influences the growth of agency banking in Kenya. Waithanji (2012) found out that there was a link between agency banking and financial deepening. Though the study could not be determined due to low number of banks that have implemented it and that the impact may become clearer once all banks adopt agency banking. Mwangi (2012) recommended that banks should consider restructuring and reevaluate the criteria for selecting and settling on the agents to cater for the liquidity problem. She advocates for further study to be done on factors that influenced the growth of agency banking in Kenya.

Mwangi (2012) established that cost effectiveness (infrastructure, human resource and security) associated with agency banking positively influenced the financial performance of the banks in Kenya hence concluding that liquidity availability in agency outlets affected the performance of commercial banks in Kenya which was in agreement with an earlier study done by Honoran (2007). Honoran advocates for further study to be done on factors that influenced the growth of agency banking in Kenya. Watiri (2013) found that the main factors influencing the adoption of agency banking among commercial banks in Kenya include: cost reduction, enhancement of customer experience and expanded presence by banks particularly in remote areas. The Watiri study therefore recommends that banks should adopt a risk based approach to the supervision and regulation of agency banking while putting sufficient security measures in place. The study suggested further research to investigate the factors which influence other agencies performance in other sectors apart from the banking sector and also another study on the same topic but in other banks to establish whether the findings can be generalized.

\section{Research Methodology}

The study used probability statistical research design and a target population of four commercial banks in Kenya; Kenya Commercial Bank (KCB), Family Bank, Cooperative Bank and Equity Bank; 10 merchants were selected from each bank as the agents and 4 relationship managers as representatives of the banks making a total of 44 respondents. Purposive sampling was used to identify agents from the four commercial banks sampled for the study. These were: Equity agent, Pesa pap, KCB mtaani, Coop jirani. According to Kothari (2004) a questionnaire is a research instrument consisting of a series of questions and other prompts, printed or typed in a definite order on a form or set of forms for the purpose of gathering information from respondents. Commercial banks have a known characteristic of having widely adopted agency banking and began this venture as a competitive edge as well as profit and wealth maximization. Merchants were similarly sampled through purposive sampling. The sample size was 10 merchants each from the 4 banks and 4 relationship managers from the four banks yielding a total of 44 respondents. Kothari, (2004) defines purposive sampling as a small sample with known characteristics to be studied intensively. A merchant is a business person who trades 
in commodities produced by others, in order to earn a profit. Questionnaires were used to collect primary data for the study.

Data was collected upon getting a research permit from the Kenya National council for Science, Technology and Innovation. Permission was also sought from the four targeted commercial banks. The drop and pick technique was adopted for purposes of collecting data. Secondary data on bank performance was obtained from financial statements and other from the sampled banks reports. Data was analyzed using descriptive analysis (means and standard deviation) and multiple regression analysis (standard). The regression model is captured below:

$Y_{i}=\beta_{0}+\beta_{1} x_{1}+\beta_{2} x_{2}+\beta_{3} x_{3}+\varepsilon$

Where:

$\mathrm{Y}_{\mathrm{i}}-$ Bank performance (Transaction time, profitability, loan book and liquidity)

$\beta_{0}-$ Constant Term

$\beta_{1} B_{3}-$ Beta coefficients

$\mathrm{X}_{1}$-Administrative challenges

$\mathrm{X}_{2}$ - Reliability

$\mathrm{X}_{3}$ - Operational challenges

$\varepsilon-$ Error term

A number of preliminary tests were carried out to precede multiple regression analysis. Normality test was conducted to determine whether sample data was drawn from a normally distributed population (Normadiah \& Wah, 2011). Multicollineality was tested using correlation matrices. The Variance Inflation factor was found to be 1.211. Homoscedasticity was tested using the Levene statistic which SPSS computes test for homogeneity of variances (Hedayat, 2009). The p-value was zero which was less than 0.05 indicating the null hypothesis of equal variances was rejected. R-value was .803 indicating that there as a strong positive correlation between adoption of agency banking and bank performance of four selected commercial banks in Kenya

\section{Results And Findings}

The results of the analyses were presented in tables as shown below. The hypotheses were to singly test the effect of agency banking administrative challenges, agency banking reliability and agency banking operational challenges on bank performance of the selected Commercial Banks in Kenya.

Table 1 below presents results on correlation analysis and coefficient of determination.

Table 1: Model Summary Table

\begin{tabular}{|l|l|l|l|l|}
\hline Model & $\mathrm{R}$ & $\mathrm{R}$ Square & Adjusted R Square & Std. Error of the Estimate \\
\hline 1 & $.803^{\mathrm{a}}$ & .645 & .615 & .57462 \\
\hline \multicolumn{2}{|l}{ a. Predictors: (Constant), Operational challenges, Administrative challenges, Reliability } \\
\hline
\end{tabular}

In view of the results in Table 1 above, the R-value of .803 indicate a strong positive correlation between challenges associated with adoption of agency banking and bank performance of the selected commercial banks in Kenya. In view of the coefficient of determination (R-square) of .645, the three key challenges account for $64.5 \%$ in variability in bank performance of the selected banks. Table 2 below presents results on the goodness of fit with respect to the model overall.

Table 2: ANOVA Table

\begin{tabular}{|c|c|c|c|c|c|c|}
\hline \multicolumn{7}{|c|}{ ANOVA $^{\mathrm{a}}$} \\
\hline \multicolumn{2}{|c|}{ Model } & Sum of Squares & Df & Mean Square & $\mathrm{F}$ & Sig. \\
\hline \multirow[t]{3}{*}{1} & Regression & 21.589 & 3 & 7.196 & 21.795 & $.000^{\mathrm{b}}$ \\
\hline & Residual & 11.887 & 36 & .330 & & \\
\hline & Total & 33.476 & 39 & & & \\
\hline \multicolumn{7}{|c|}{ a. Dependent Variable: Bank Performance } \\
\hline \multicolumn{7}{|c|}{ b. Predictors: (Constant), Operational challenges, Administrative challenges, Reliability } \\
\hline
\end{tabular}

The results in Table 2 above indicate that F-statistic was 21.795 and a p-value of 0.000 (which is less than the significance level of 0.05) indicating that the model overall was statistically significant. Hence, the challenges associated with the adoption of agency banking have a significant effect on bank performance of the four selected commercial banks in Kenya.

Table 3 below presents coefficients and p-values associated with the study variables.

\begin{tabular}{|c|c|c|c|c|c|c|c|}
\hline \multirow[t]{2}{*}{ Model } & \multicolumn{2}{|c|}{$\begin{array}{l}\text { Unstandardized } \\
\text { Coefficients }\end{array}$} & $\begin{array}{l}\text { Standardized } \\
\text { Coefficients }\end{array}$ & \multirow[t]{2}{*}{$\mathrm{t}$} & \multirow[t]{2}{*}{ Sig. } & \multicolumn{2}{|c|}{$\begin{array}{l}\text { 95.0\% Confidence Interval for } \\
\text { B }\end{array}$} \\
\hline & $\mathrm{B}$ & Std. Error & Beta & & & $\begin{array}{l}\text { Lower } \\
\text { Bound }\end{array}$ & Upper Bound \\
\hline
\end{tabular}




\begin{tabular}{|l|l|l|l|l|l|l|l|l|}
\hline 1 & (Constant) & .249 & .607 & & .410 & .684 & -.982 & 1.479 \\
\cline { 2 - 9 } & $\begin{array}{l}\text { Administrati } \\
\text { ve challenges }\end{array}$ & -.003 & .213 & -.001 & -.013 & .990 & -.434 & .428 \\
\cline { 2 - 8 } & Reliability & .549 & .092 & .669 & 5.934 & .000 & .361 & .736 \\
\cline { 2 - 9 } & $\begin{array}{l}\text { Operational } \\
\text { challenges }\end{array}$ & .376 & .167 & .246 & 2.247 & .031 & .037 & .715 \\
\hline
\end{tabular}

In view of table 3 above, there seems to be no much concern on multicollinearity considering the high tolerance and low VIF factors. The regression function extracted from the table is presented below.

$y_{i}=\beta_{0}+\beta_{1} x_{1}+\beta_{2} x_{2}+\beta_{3} x_{3}+\varepsilon$

Where:

$y_{i}=$ Bank performance

$\beta_{0}=$ Intercept, $\beta_{1}-\beta_{3}=$ the regression coefficients; $x_{1}=$ Administrative challenges; $x_{2}=$ Reliability; $x_{3}=$

Operational challenges; $\varepsilon=$ Error term.

From Table 3, the regression function is extracted as follows:

$y_{i}=0.249-0.003 x_{1}+0.549 x_{2}+0.376 x_{3}+0.607$

The regression model indicates that bank performance was dependent of administrative challenges, reliability and operational challenges to the extent of the betas and p-values. The model also indicated that, if all the predictors were to be held constant there would still be a positive performance of 0.249 a one unit increase of administrative challenges would lead to negative change in performance of 0.003 units, all else held constant. One unit increase in reliability would cause 0.549 units increase in bank performance, all else held constant. A one unit increase in operational challenges would cause 0.376 units increase in bank performance, all else held constant.

The statistical significance of each challenge on bank performance was equally tested. In view of the results in Table 3 above are presented as follows. Administrative challenges were found not to be statistically significant in explaining bank performance since the p-value was 0.990 (which is higher than the significance level of 0.05 ). Reliability was found to be statistically significant in explaining bank performance ( $p$-value of 0.000 ); similarly, operational challenges were found to have a significant effect in explaining bank performance since the p-value was 0.0034).

\section{Discussion}

The study established that Cooperative bank, Family bank, Kenya Commercial Bank and Equity Bank offered agency banking for withdrawals and deposit transactions, account opening and interbank transfers, customers pay their bills and remittance purposes to increase income and improve its financial performance. Agency banking services as compared to the use of mobile banking are yet to be appreciated (Mosoti \& Mwaura, 2014). Mosoti and Mwaura indicated that despite significance of the sector to the Kenyan economy, it remains unclear if adoption of agency banking in commercial banking sector has a significant effect on bank performance. From the regression analysis, the study found that there existed a positive relationship between performance and adoption of agency banking indicating that agency banking improve financial performance of commercial banks through lowering operating costs, increased income and reducing costs.

Argamo (2015) indicates that there is a positive and significant relationship between accessibility of banking services, low cost of service and customer transactions as a result of agency banking. Argamo's study found that the need to increase investment, diversify in the market, increase loans, increase market share and improving of savings, improving market penetration, increase competition from other banks, reduce credit risk, lower operating costs, attract more customers, increase deposits from customer centrism to influence use of agency banking in commercial banks. Irura and Munjiru (2013) studied challenges of implementing agency banking in Kakamega County, Kenya. The study found out that implementation could be explained by fraud literacy levels, technological issues and liquidity problem. Irura and Munjiru study findings show that staff cost were minimized, average transaction cost in the bank was reduced due to agency banking and that banking transactions increased bank savings. The study found that agency banking improves bank efficiency and reduces costs of provisioning implying that agency banking greatly enhances efficiency in bank operations improving bank profitability.

Agalla (2014) sought to establish challenges facing implementation of agency banking at Kenya Commercial Bank, Mombasa County with an objective of establishing whether risks associated with agency banking, policies and procedures governing agency banking, technological operations and awareness were hindrances to the implementation of agency banking. Munyoki and Ngigi (2011) conducted a study on 
challenges of electronic banking adoption among the commercial banks in Kenya the study found out that banks had partially adopted electronic banking as a strategy and the issue of security was found to be the most critical factor influencing electronic banking adoption. From the findings, agency banking reduced operation cost for the commercial banks to a very great extent, indicating that reduction in bank operations cost such as administration. The study found that commercial banks were charging customers for agency banking increasing banks income and interest improving banks financial performance hence reliability. The study established that usage of agency banking had influenced saving. Increased bank income and time saving in carrying out transactions improving banks returns and improved bank performance.

The study further found that banks incurred installation, administration and transaction costs, staff costs through salary and wages of employees supervising the agency banking when administering loan referrals. The study found that the banks use agency banking in offering loans, earning more interest and increasing bank revenues. From the findings, the study concludes that agency banking has increased bank revenues by management efficiency, earn more interest from agency banking influence bank return on assets, that bank reduces transaction cost increasing bank return.

\section{Conclusion and Recommendation}

The study concluded that majority of the agent's lack the rights skills since some of them are secondary school graduates. There were also two agents who were primary school leavers. This shows that educational qualifications are not considered in agents. Agency banking has been adopted by many who use it over ten times a month.

The study further concludes that the inception of an agency takes a lot of time which is caused by the laid down guidelines by the banks. The guidelines were not limiting many from being agents. Majority of the respondents reported that there were restrictions but they did not hinder the implementation of the agency program. Availability of resources affected the implementation of operational policies, administration hierarchy and reliable systems.. Agency banking is a business (just like any other) which requires enough capital to start and run it. Without enough resources, human and financial, the business is bound to fail. Therefore, the reliability of the agency banking is dependent on the availability of resources. Agency banking has improved lives and livelihood of customers though the improvement is not much since not all agents can attest to this. From the findings, the study concluded that there has been an increase in customer base with the inception of agency banking. Customers no longer have to literary walk to the bank to conduct a transaction. The most famous and common ones attract more customers for example, KCB mtaani and Coop jirani. The study concluded that, despite the challenges mentioned, agency banking reduces operation costs in commercial banks. Agency banking reduces average transaction costs; increasing banks savings improve bank efficiency and reduce costs for provisioning improving banks profitability. Agency banking minimizes operation costs such as administration improving banks profitability and also is adopted by commercial banks thus increasing banks income earned through interest earned from loans, savings reduce provisioning. Increase banks sales improving profit margin. The study concluded that the charges from agency banking bill payments, real time access to product and services increasing banks income, increase profits and internal cash reserves improve asset quality improving bank financial performance.

The study further concluded that commercial banks adopted internet banking in order to reduce loan processing costs, reduce credit risk and increase interest. The study concludes further that agency banking reduces non-performing loans and increase efficiency in loan processing enhancing commercial banks return on assets. From the regression analysis, the study concluded that agency banking improves commercial bank return on assets through encouraging lowering operating costs and increased income.

The study recommends that commercial banks enhance and deploy more resources for use by agency banking agents to reduce administration cost, operation costs and increase income and improve asset quality, improving bank financial performance. Banking through agency banking has emerged as a strategic resource for achieving higher efficiency, control of operations and reduction of cost by replacing paper based and labor intensive methods with automated processes thus leading to higher productivity and profitability. Therefore, commercial banks should integrate the use of agency banking for exploring and finding new customers, enhancing speedy communication, developing new products, collecting and managing information, generating a wide range of product ideas from a wider range of resources, access documents and share technical information this can be done by the regulator Central Bank of Kenya. The study recommended to policy makers that in order to help banks improve their operations, they need to heighten awareness to the public through regular open day forums, media and exhibitions on the need and uses of agency banking, develop strategies that will capture new customers and increase transactions. 


\section{Contribution To Knowledge}

The findings of the study are of importance to the management of commercial banks to understand how agency banking affects customer satisfaction and retention hence greater profitability. Therefore, the management would decide whether it is worthwhile to substitute traditional banking for agency banking or not. Being that there are limited studies that link agency banking with profitability, the outcomes of the study are valuable empirical study and also act as local reference on agency banking for future research. The study helps academicians to follow up on studies on effects of agency banking on individual bank performance and advance the research as technology advances. The findings provide information and advice on opportunities banks can use to expand on deposit collection as well as customer service. Banking institutions are advised to integrate the use of agency banking for exploring and finding new customers, enhancing speedy communication, developing new products, collecting and managing information, generating a wide range of product ideas from a wider range of resources, access documents and share technical information done by the regulator, Central Bank of Kenya.

\section{Areas for further research}

In view of the unique findings of the study, there are certain areas that warrant further investigation. The study further recommends that a further study should be carried out to establish effect on adoption of agency banking in upcoming agencies for other commercial banks as well as credit unions and microfinance institutions when policy and procedure allow them to venture into agency banking so as a broad analysis on impact of adoption of agency banking in banking industry can be provided and why administration challenges are not significant in the adoption of agency banking. The study suggests to the academicians to find out why administration challenges are not significant in explaining bank performance as a way streamlining policies and procedures that govern the banking industry.

\section{References}

[1]. Aburime, T. U. (2008). Determinants of Bank Profitability: Company-Level Evidence from Nigeria. SSRN Electronic Journal, (1231064), 31

[2]. Agalla, T. O. (2014). The Challenges Facing the Implementation of Agency Banking In Kenya a Case Study of Kcb Limited Mombasa County, 16(11), 76-95.

[3]. Allen, F., \& Gale, D. (2004). Competition and Financial Stability 1. J Money Credit Bank, 36(3), 453-480.

[4]. Berger, A. N., Demirgüç-Kunt, A., Levine, R., \& Haubrich, J. G. (2004). Bank concentration and competition: An evolution in the making. Journal of Money, Credit and Banking, 36(3), pp. 433-451.

[5]. Calleo Solutions-Research Division. (2014). Accessing the Unbanked : Branchless Banking in Africa, (September).

[6]. Central Bank of Kenya. (2013). Developments in the kenyan banking sector for the quarters ended 31st Mar, 30th and 30th Sep 2013

[7]. Hussain, S. M. (2014). Measuring Quality of Electronic Service ( E- Service ) In Banking, 4(3), 350-359.

[8]. Irura, N. S., \& Munjiru, M. M. (2013). Technology Adoption and the Banking Agency in Rural Kenya. Journal of Sociological Research, 4(1), 249-266.

[9]. Jensen, M. C., \& Meckling, W. H. (1976). Theory of the Firm : Managerial Behavior , Agency Costs and Ownership Structure Theory of the Firm : Managerial Behavior, Agency Costs and Ownership Structure. Journal of Financial Economics, 3(4), 305360 .

[10]. Karani, R. M. (2013). the Effect of Liquidity Management on Profitability of Commercial Banks in Kenya. Journal

[11]. Karimi, L. (2011), The extent of implementation of agency banking among commercial banks in Kenya. Unpublished MBA Thesis, University of Nairobi

[12]. Kiragu, D., Ndwiga, J. M., \& Lecturer, S. (2006). the Reltionship Between Agency Banking and Financial Performance of Commercial Banks in.

[13]. Kithuka, B. K (2012), Factors influencing growth of agency banking in Kenya: the case of Equity bank, Kwale County, Kenya. Unpublished MBA Thesis, University of Nairobi.

[14]. Kothari, C. R. (2004). Research Methodology: Methods \& Techniques. New Age International (P) Ltd.

[15]. Kumar, Anjali. 2006 "Expanding Bank Outreach through retail Partnerships: Correspondent Banking in Brazil." World Bank Working Paper No.85 Washington,D.C, : World Bank

[16]. Lee, K. S., Lee, H. S., \& Kim, S. Y. (2007). Factors Influencing the Adoption Behavior of Mobile Banking. Journal of Internet Banking and Commerce, 12(10), 1-9.

[17]. Mandrile, M. (n.d.). A new agent model By Daniel Mauricio Alarcón Lozano Counsel , General Directorate of Financial Regulation Ministry of Finance and Public Credit, Colombia.

[18]. Mas, I., \& Radcliffe, D. (2011). Scaling mobile money. Journal of Payments Strategy \& Systems, 5(3),298-315.

[19]. Muiruri, J. K., \& Ngari, J. M. (2014). Effects of Financial Innovations on the Financial Performance of Commercial Banks in Kenya, 4(7), 51-57.

[20]. Mwangi M.K. (2007). Factors Influencing Financial Innovation in Kenya ${ }^{e e}$ S Securities Market: A Study of Firms Listed at the NSE. Unpublished Master of Business Administration Project, University of Nairobi.

[21]. Mwaura, R. W. (2014). An Investigation on Slow Adoption of Agent Banking Services in Kenya as Strategic Response by Commercial Banks : A Case Study of Roysambu Constituency, 2(3), 1-13.

[22]. Nefa, C. (2013). Agent Banking Operations as a Competitive Strategy of Commercial Banks in Kisumu City Nefa Chiteli Kenya Commercial Bank Limited. International Journal of Business and Social Science, 4(13), 306-324.

[23]. Sahut, J. (2011). Determinants of Banking distress and Merger as Strategic Policy to Resolve Distress, $28(1), 138-146$.

[24]. Saropa, J. Watiri (2013). Adoption of Agency Banking by Equity Bank Kenya Limited in its International Business operations. International Journal of Social Sciences and Entrepreneurship, 1(2), 36-39.

[25]. Waithanji, M. N. (2012). The impact of agent banking as a financial deepening initiative in Kenya. Unpublished MBA Thesis, University of Nairobi. 